\title{
Islet autoimmunity in infants with a Type I diabetic relative is common but is frequently restricted to one autoantibody
}

\author{
P. G. Colman ${ }^{1}$, C. Steele ${ }^{2}$, J.J. Couper ${ }^{3}$, S. J. Beresford ${ }^{3}$, T. Powell ${ }^{3}$, K. Kewming ${ }^{4}$, A. Pollard ${ }^{3}$, S. Gellert ${ }^{4}$, B. Tait ${ }^{4}$, \\ M.Honeyman ${ }^{5}$, L.C.Harrison ${ }^{5}$ \\ ${ }^{1}$ Department of Diabetes and Endocrinology, The Royal Melbourne Hospital, Victoria, Australia \\ ${ }^{2}$ Burnet Clinical Research Unit, Walter and Eliza Hall Institute of Medical Research, Royal Melbourne Hospital, Victoria, \\ Australia \\ ${ }^{3}$ Women's and Children's Hospital, University of Adelaide, Adelaide, Australia \\ Department of Diabetes and Endocrinology, \\ ${ }^{4}$ Department of Pathology, The Royal Melbourne Hospital, Victoria, Australia \\ ${ }^{5}$ Walter and Eliza Hall Institute of Medical Research, The Royal Melbourne Hospital, Victoria, Australia
}

\section{Abstract}

Aims/hypothesis. To determine the sequence of development of islet autoantibodies and their relation to HLA genes in infants at risk for Type I diabetes followed from birth.

Methods. We followed 357 (189 male, 168 female) infants, with a first degree relative with Type I diabetes for a mean of 3 years from birth. Human leukocyte antigen typing and assays for insulin autoantibodies (IAA), glutamic acid decarboxylase antibodies (GA$\mathrm{DAb}$ ) and tyrosine phosphatase IA2 (IA2Ab) antibodies were done on cord blood, and venous blood was sampled every 6 months for IAA, GADAb and IA $2 \mathrm{Ab}$.

Results. We did not find any antibodies in 263 (73\%) infants; $50(14 \%)$ were positive for a single antibody once, $19(5 \%)$ for a single antibody more than once and $25(7 \%)$ for two or more antibodies. Of the latter, 10 (2.8\% overall) were persistently positive; they had higher frequencies of HLA DR4 $(p<0.01)$ and HLA DR3, $4(p<0.05)$. Of the group persistently positive for two or more antibodies four infants developed diabetes. Insulin autoantibodies were the first ones to develop in $64 \%$ of infants with two or more antibodies.

Conclusion/interpretation. Infants with high risk HLA-DR alleles and multiple antibodies at high risk for diabetes were identified. A much larger group of infants had transient low level increases usually of a single antibody. Whereas transient low level positivity could be attributed to difficulties with assay technique and cut off levels for normality, the results overall support the phenomenon of transient 'self limited' islet autoimmunity in at risk infants. [Diabetologia (2000) 43: 203-209]

Keywords Pre-clinical Type I diabetes, infants, insulin autoantibodies, GAD antibodies, IA2 antibodies, HLA.
Type I (insulin-dependent) diabetes mellitus is caused by immune-mediated destruction of the insulin-secreting beta cells in the islets of the pancreas [1]. Studies in first-degree relatives of patients with Type I diabetes [2-4] have shown conclusively that

Received: 10 Juni 1999 and in revised form: 27 August 1999

Corresponding author: Dr. P. Colman, Department of Diabetes and Endocrinology, Royal Melbourne Hospital, PO 3050, Victoria, Australia.

Abbreviations: IAA, Insulin autoantibodies; GADAb, glutamic acid decarboxylase antibodies; IA2Ab, tyrosine phosphatase IA 2 antibodies; ICA, islet cell antibodies; ROC, receiver operator curve. autoantibodies to islet antigens precede the onset and can be used to predict clinical disease. Initially, islet cell antibodies (ICA) and insulin autoantibodies (IAA) were used to identify relatives at high risk. Recently, several studies have concluded that antibodies to glutamic acid decarboxylase (GADAb) and to the putative tyrosine phosphatase IA2 (IA2Ab) in combination are as disease specific and sensitive as ICA, simpler to analyse and thus more suitable for preclinical screening [5-8].

Many questions remain to be answered regarding the natural history of development of islet autoimmunity that are central to furthering our understanding of pathogenesis and developing screening and prevention strategies. These include the timing and se- 
quence of appearance of autoantibodies. Is the immune response to only one islet antigen and then 'spreads' to encompass others, or is it simultaneously to more than one antigen? Identification of a primary, inciting antigen would have major implications for the design of targeted prevention strategies.

Most studies in first-degree relatives are of older children and young adults and have not tested subjects repeatedly over time. In a prospective study from birth, however, it was shown [9] that islet autoimmunity frequently begins at an early age. In that study 66 offspring of mothers with Type I diabetes to the age of 9 months, and 28 to the age of 2 years were investigated. At 9 months, three infants had IAA but none ICA. At age 2 three infants were antibody positive (two IAA, one both ICA and IAA). There were no measurements of GADAb and $\mathrm{IA} 2 \mathrm{Ab}$. It was then reported that 513 first-degree related infants from the German BABYDIAB Study were followed to age 9 months, 214 had been followed to 2 years and 37 to 5 years [10]. Thirty seven children developed islet antibodies; at 2 years $2.3 \%$ had ICA, 7\% IAA, 4.2\% GADAb and $2.8 \%$ IA $2 \mathrm{Ab}$, with $8.2 \%$ having at least one antibody. No pattern or sequence of antibody development was, however, apparent. Four children developed diabetes during follow-up; all had two or more antibodies prior to diagnosis. In a more recent update of 1353 infants [11] it was found that by 2 years of age antibodies had appeared in $11 \%$ of the children with $3.5 \%$ having more than one antibody; nine children developed diabetes during follow-up. In the German BABYDIAB study $20 \%$ of HLA DR $3 / 4$ and HLA DR4/4 offspring of mothers with Type I diabetes developed islet antibodies by age 2 years [12]. Two other studies, the Diabetes Autoimmunity Study in the Young (DAISY) [13] and the Finnish IDDM Prediction and Prevention Project [14] are now evaluating the feasiblity of population newborn screening for high-risk HLA genes, with follow-up repeated antibody testing.

Key questions regarding the natural history of islet autoimmunity remain unanswered and further prospective studies relating genetic and environmental factors to the development of islet autoimmunity are required.

We have followed, prospectively from birth, infants with a first-degree relative with Type I diabetes to determine the sequence of development of islet antibodies and their relation to genetic and environmental factors. Recently, we reported that the duration of exclusive breast feeding and the age of introduction of cow's milk (similar to another recent retrospective study [15]), are not related to the development of islet antibodies [16]. Here we report the development of islet antibodies in relation to HLA status.

\section{Methods}

Subjects. We ascertained 357 newborns (189 males, 168 females) with a first-degree relative with Type I diabetes during pregnancy and followed them prospectively from birth for a mean of 3.0 years (range 0.09 to 7.18 ). The probands included 196 mothers, 111 fathers and 41 siblings with Type I diabetes; four infants had more than one first-degree relative and five had multiple second-degree relatives with Type I diabetes. The mean age of onset of diabetes in probands was 15.5 years (15.6 for mothers, 19.2 for fathers, 4.1 for brothers and 5.0 for sisters). Twenty one children have withdrawn from the study or been lost during follow-up.

Blood testing. Venous blood samples were taken at birth (umbilical vein) and then (every 6 months thereafter) for measurement of IAA, GADAb, IA2Ab and glucose. Human leukocyte antigen typing was done with umbilical venous blood and also with blood from the proband. Antibodies were also measured in mothers with diabetes to facilitate the identification of transplacentally-acquired antibodies.

\section{Laboratory assays}

$I A A$. Insulin autoantibodies were measured in duplicate $150 \mu \mathrm{l}$ aliquots of serum by a modification of the ${ }^{125}$ I-insulin immunoprecipitation assay [17]. To conserve serum, non-specific binding in the presence of an excess of unlabelled insulin was not measured. The reference range $(<5.5 \%)$ corresponded to the $99^{\text {th }}$ percentile derived from 190 healthy young children and adults [mean age 9.7 years (range 4.9-15.5 years)]. The inter- and intra-assay coefficients of variation were 16 and $3.9 \%$, respectively. The mean for 80 children with newly-diagnosed Type I diabetes was $6.8 \%$ (range 1.4-28.5\%); for those aged less than 5 years, 11 of $12(92 \%)$ had a mean greater than $5.5 \%$.

$G A D A b$ and $I A 2 A b$. We measured GADAb and IA $2 \mathrm{Ab}$ by precipitation of ${ }^{35} \mathrm{~S}$-methionine-labelled recombinant human proteins. Glutamic acid decarboxylase 65 and IA2 were synthesized in the TNT coupled reticulocyte lysate system (Promega, Madison, Wis., USA), as previously described [8].

The reference range for GADAb, derived by receiver operator curve (ROC) analysis of 246 healthy, young children and adults and 135 patients with newly-diagnosed Type I diabetes was $5 \mathrm{U}$ or less, the 98.5 th percentile for the healthy control subjects. The inter- and intra-assay coefficients of variation were 12 and $5 \%$, respectively. We found that 103 of 135 (76\%) patients with newly-diagnosed Type I diabetes had GADAb of more than 5 U. In the International GAD Proficiency Test 2 , the assay scored $100 \%$ for sensitivity, specificity, validity and consistency. The normal range for IA2Ab, derived by ROC analysis of 145 healthy, young children and adults and 94 patients with newly-diagnosed Type I diabetes was $3 \mathrm{U}$ or less, the 97th percentile for normal control subjects. The inter- and intra-assay coefficients of variation were $20 \%$ and less than $1 \%$, respectively. Of 94 patients 72 $(78 \%)$ with newly-diagnosed Type I diabetes had more than $3 \mathrm{U}$ of IA $2 \mathrm{Ab}$. In the International IA-2A Proficiency Test 1 , the assay scored $100 \%$ for sensitivity and specificity, validity and consistency.

$I C A$. Islet cell antibodies were assayed by indirect immunofluorescence as described previously [8] in the four infants who were repeatedly positive for GADAb. 
Repeat antibody testing in positive samples. Samples that tested positive were always confirmed by retesting in a separate assay, except positive IAAs because the IAA assay required $300 \mu \mathrm{l}$ and could not be repeated in approximately $50 \%$ of the cases. Seroconversions from positive to negative were also retested.

In babies with a diabetic mother, antibodies detected in cord blood or during the first 12 months were regarded as being transplacentally-acquired unless the mother was negative for antibodies. Transplacentally-acquired antibodies were excluded from the analysis.

HLA typing. HLA class I (A,B) typing was done by a standard serological microlymphocytotoxicity assay using $\mathrm{T}$ lymphocytes separated from cord blood [18]. Class II (DR) typing was done on polymerase chain reaction-amplified DNA using sequence specific oligonucleotides according to the 11th International Histocompatibility protocol [19].

HLA typing has been completed on 255 subjects of the study group [180 of $263(68 \%)$ antibody-negative, 34 of 50 $(70 \%)$ antibody-positive on one occasion only, 18 of 19 (95\%) single antibody-positive on more than one occasion and 23 of $25(92 \%)$ with multiple antibodies] and compared with 201 control subjects without a personal or family history of Type I diabetes or other autoimmune disease.

Statistics. The frequencies of HLA DR alleles were compared using Fisher's exact test.

\section{Results}

Of the 357 infants, $263(74 \%)$ remained antibody negative throughout a mean follow-up period of 3 years, 50 of $357(14 \%)$ had a single antibody detectable on only one occasion (mean follow-up 4.11 years), 19 (5\%) had a single antibody detected on more than one occasion (mean follow-up 4.41 years) and 25 (7\%) had two or more antibodies detected (mean follow-up 4.5 years). Of those without antibodies, the proband was a father in 78 , a mother in 146 and a sibling in 32 cases; seven had multiple relatives with diabetes.

Single antibody on one occasion only. Of the 50 infants with antibodies detected on only one occasion, the father was the proband in 20 , the mother in 25 and a sibling on five occasions. Tyrosine phosphatase IA 2 antibodies were detected in 21, IAA in 19 and GADAb in 10 subjects. In general the antibody levels were low. Antibodies were detected at a mean age of 21 months (range 6-54) for IA2Ab, 21 months (range 10-48) for IAA and 23 months (range 6-36) for GADAb (Fig. 1). Relationship with proband had no association with the age of detection or type of antibody.

Single antibody on more than one occasion. Of the 19 infants with a single antibody detected on more than one occasion (Table 1), the father was the proband in four, the mother in 12, a sibling in one and both a parent and sibling on two occasions. The most frequently detected antibody was IAA in 11 subjects;
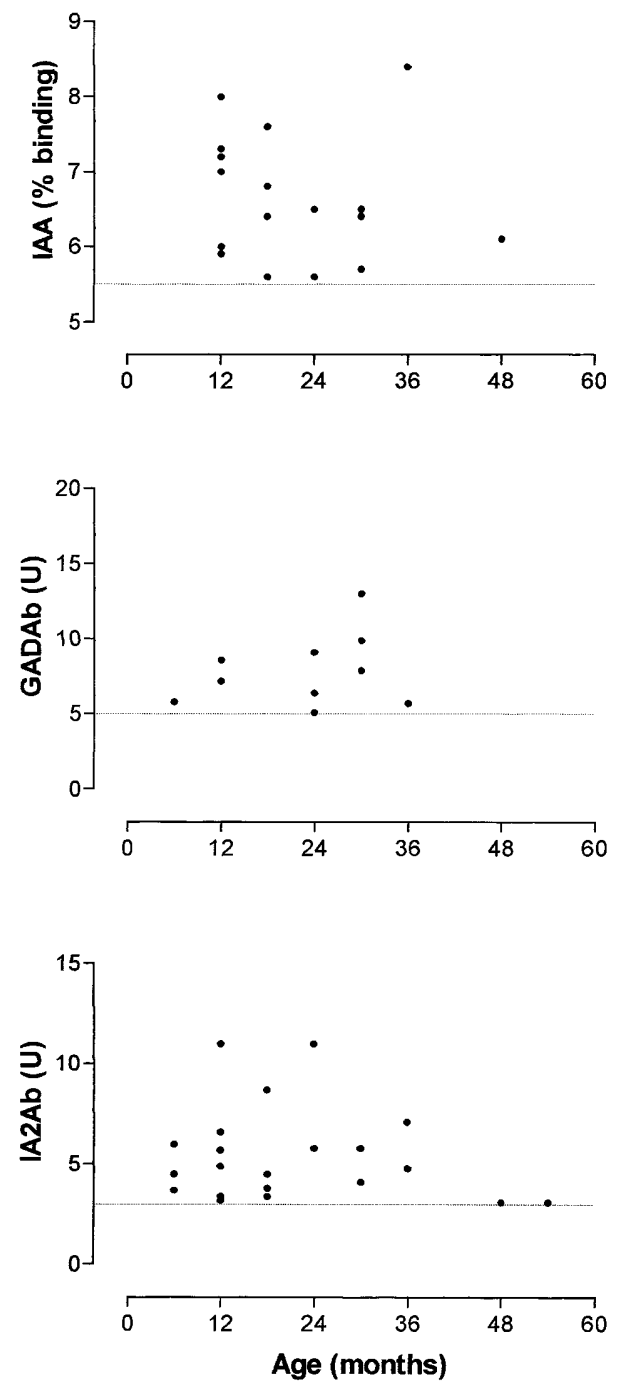

Fig. 1. Antibody levels according to age in infants with transient increase of a single antibody

GADAb and IA2Ab were each detected in four. In all but three infants (Table 1: subjects 3,12 and 18) antibodies were detected in consecutive samples. All infants with GADAb remained positive in sequential samples. None of the infants, however, was ICA positive. In one infant (Table 1, subject 18), IA2Ab decreased from the 6- to the 12-month sample; however, as the mother's serum was negative for IA $2 \mathrm{Ab}$, transplacental passage was unlikely.

Two or more antibodies. Sixteen infants (7\%) (14 males, 11 females; proband father in nine, mother in 13 and sibling in 3 cases) had two antibodies (IAA and IA2Ab in five, IAA and GADAb in nine and GADAb and IA2Ab in two) and nine had all three antibodies (Table 2).

Insulin autoantibodies were the first antibodies detected in 15 of 25 infants (60\%) (alone in eight, with $\mathrm{GADAb}$ in five and with IA $2 \mathrm{Ab}$ in one). The first antibody detected in 12 of 25 infants $(48 \%)$ was GA- 
Table 1. Antibody, diabetes proband and age at antibody detection in infants with one antibody detected on more than one occasion (nd = not done)

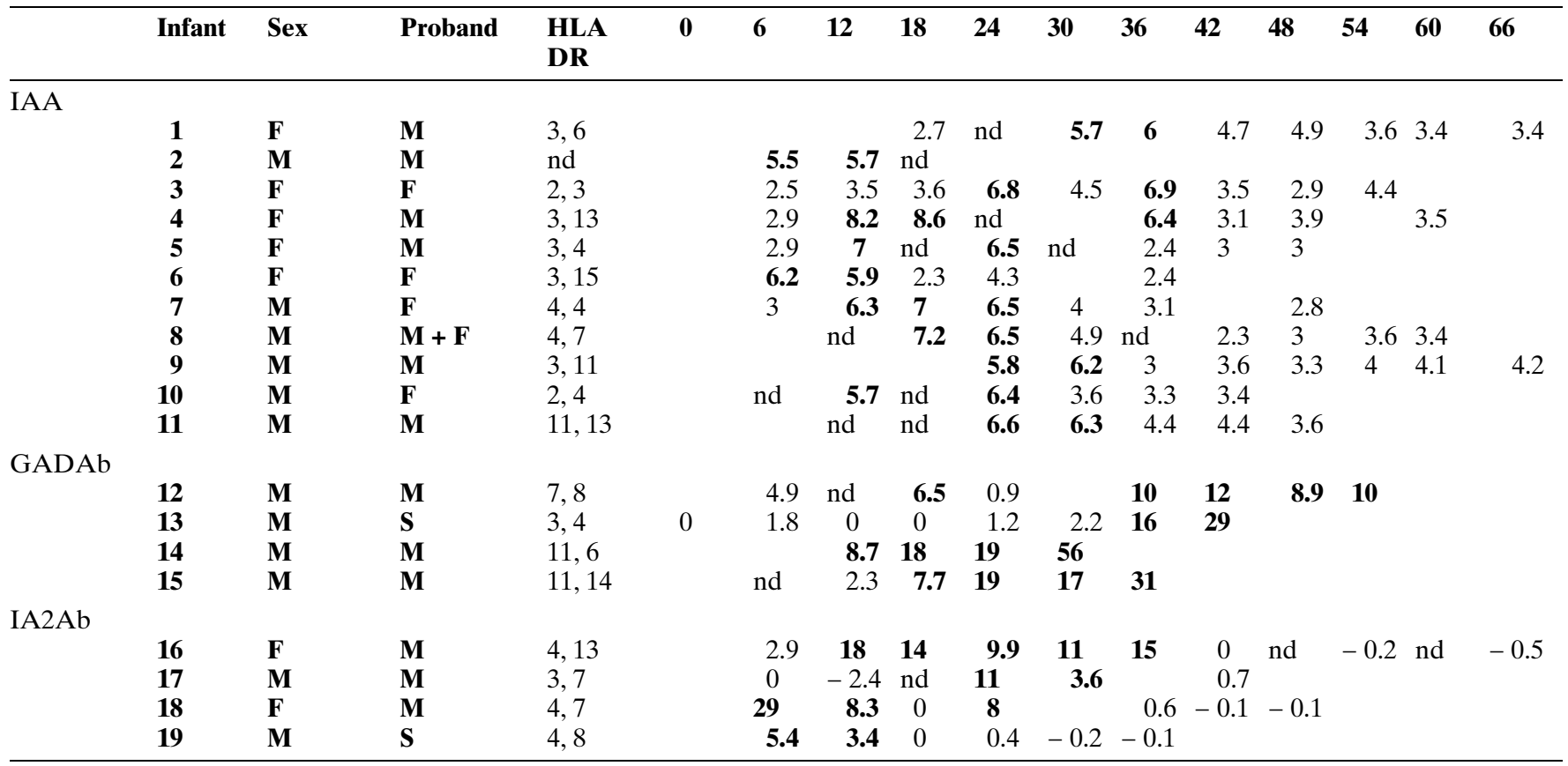

$\mathrm{DAb}$ (alone in five, with IAA in five and with IA $2 \mathrm{Ab}$ in two). The first antibody detected in 6 of 25 subjects $(24 \%)$ was IA2Ab (alone in two, with GADAb in two and with IAA in two). In one infant (Table 2, subject 25), all three antibodies appeared simultaneously for the first time at the age of 18 months. The age at detection of single or multiple antibodies was variable with no difference in the mean age at detection evident for the different combinations (Table 3 ).

HLA typing. Compared with control subjects, the study group was characterised by significant increases in the frequencies of class II alleles DR3 $(p<0.0001)$, DR4 $(p<0.0001)$, DR 3,4 $(p<0.005)$ and DR3 and/ or $4(p<0.0001)$ and decreases in DR2 $(p<0.0001)$, DR5 $(p<0.0001)$, DR $6(p<0.0001)$ and DR 7 $(p<0.01)$. All four subgroups showed significant increases in DR 3 and/or 4 compared with control subjects, but there were no significant differences between the antibody negative and any antibody positive group. Infants with two or more repeatedly positive antibodies, however, (Table 2: subjects 15, 17-25) had significantly increased frequencies of HLA DR4 $(p<0.01)$ and HLA DR 3,4 $(p<0.05)$ compared with the total study group.

Development of Type I diabetes. Four infants (Table 2, subjects 17, 21, 24 and 25) developed diabetes.

Infant 17, who has HLA DR3, 4 with a maternal proband, developed diabetes at age 42 months after being IAA and GADAb positive at 18 months. Un- fortunately, there was insufficient serum for the IAA assay at 12 months, so we cannot be certain that his IAA were not increased prior to 18 months. By 24 months all three antibodies were positive. His first phase insulin release (FPIR $=$ sum of serum insulin concentrations 1 and $3 \mathrm{~min}$ after $0.5 \mathrm{~g} / \mathrm{kg}$ intravenous glucose) was $25 \mathrm{mU} / \mathrm{l}$ at 36 and $6 \mathrm{mU} / \mathrm{l}$ at 42 months.

Infant 21, who is HLA DR 3, 4 with a maternal proband, developed diabetes at age 17 months after being GADAb positive at 6 months and 12 months. Immediately prior to diagnosis all three antibodies were positive.

Infant 24, who is HLA DR 4,4 with a maternal proband, developed diabetes at age 30 months after being IAA and GADAb positive at 24 months. All antibodies were negative at age 12 months, and a sample could not be obtained at 18 months. At the time of diagnosis all three antibodies were positive.

Infant 25 , who is HLA DR 4,7 with a sister as proband, developed diabetes at age 24 months after being positive for all antibodies at 18 months.

\section{Discussion}

This study is one of the most detailed yet of infants with a first-degree relative with Type I diabetes who have been followed every 6 months from birth for the development of islet autoimmunity and diabetes. Of 357 babies followed for a mean of 3.0 years, $73 \%$ were antibody negative, $14 \%$ had a single antibody detected on only one occasion, $5 \%$ had a single anti- 
Table 2. Antibody and age at detection in infants with two or more antibodies detected (nd $=$ not done, $*=$ age of diabetes development)

\begin{tabular}{|c|c|c|c|c|c|c|c|c|c|c|c|c|c|c|c|}
\hline \multirow[t]{2}{*}{ Infant } & \multirow[t]{2}{*}{ Sex } & \multirow[t]{2}{*}{ Proband } & \multirow[t]{2}{*}{ Antibody } & \multirow{2}{*}{$\begin{array}{l}\text { HLA } \\
\text { DR }\end{array}$} & \multicolumn{11}{|c|}{ Age (Months) } \\
\hline & & & & & 0 & 6 & 12 & 18 & 24 & 30 & 36 & 42 & 48 & 54 & 60 \\
\hline 1 & $\mathrm{M}$ & $\mathrm{F}$ & $\begin{array}{l}\text { IAA } \\
\text { GADAb } \\
\text { IA2Ab }\end{array}$ & 3,4 & & & $\begin{array}{l}0 \\
0\end{array}$ & $\begin{array}{l}\text { nd } \\
0 \\
\mathbf{7 . 1}\end{array}$ & $\begin{array}{r}5.7 \\
2.7 \\
-3.7\end{array}$ & $\begin{array}{c}\text { nd } \\
0 \\
0.6\end{array}$ & $\begin{array}{r}\text { nd } \\
4.6 \\
0.6\end{array}$ & $\begin{array}{l}5 \\
2.6 \\
1.1\end{array}$ & $\begin{aligned} & 3.8 \\
& 0 \\
- & 1.9\end{aligned}$ & $\begin{array}{l}2.8 \\
4.4 \\
0.1\end{array}$ & \\
\hline 2 & $\mathrm{~F}$ & $\mathrm{~F}$ & $\begin{array}{l}\text { IAA } \\
\text { GADAb } \\
\text { IA2Ab }\end{array}$ & 3,4 & & $\begin{array}{l}\text { nd } \\
0 \\
-9.5\end{array}$ & $\begin{aligned} & 4.6 \\
& 2.5 \\
- & 3\end{aligned}$ & $\begin{aligned} & 4.9 \\
& 0.2 \\
- & 3\end{aligned}$ & $\begin{array}{c}4 \\
1.8 \\
-2.4\end{array}$ & $\begin{array}{c}\text { nd } \\
0.3 \\
0.3\end{array}$ & $\begin{array}{r}2.9 \\
8.4 \\
-3.3\end{array}$ & $\begin{array}{l}\mathbf{5 . 6} \\
0.5 \\
\mathbf{5}\end{array}$ & $\begin{array}{c}4 \\
0 \\
-1.7\end{array}$ & $\begin{aligned} & 3.2 \\
& 0 \\
- & 0.3\end{aligned}$ & $\begin{aligned} & 4.4 \\
& 0 \\
- & 0.5\end{aligned}$ \\
\hline 4 & $\mathrm{~F}$ & M & $\begin{array}{l}\text { IAA } \\
\text { GADAb } \\
\text { IA } 2 A b\end{array}$ & 3,4 & & $\begin{array}{r}\text { nd } \\
0 \\
0\end{array}$ & $\begin{array}{r}\text { nd } \\
0 \\
0\end{array}$ & $\begin{array}{l}4.8 \\
0 \\
0.2\end{array}$ & $\begin{array}{l}\text { nd } \\
0 \\
0.6\end{array}$ & $\begin{array}{l}\mathbf{6 . 8} \\
0 \\
1.2\end{array}$ & $\begin{array}{l}3.2 \\
0 \\
4.7\end{array}$ & $\begin{array}{l}3.1 \\
0\end{array}$ & $\begin{array}{r}2.1 \\
-0.1\end{array}$ & $\begin{array}{r}2.1 \\
0.3 \\
-0.1\end{array}$ & $\begin{array}{r}0.3 \\
-0.1\end{array}$ \\
\hline 5 & M & M & $\begin{array}{l}\text { IAA } \\
\text { GADAb } \\
\text { IA } 2 A b\end{array}$ & 1,7 & & $\begin{array}{r}5.2 \\
-1.6 \\
-9.4\end{array}$ & $\begin{aligned} & \mathbf{5 . 7} \\
- & 3 \\
- & 7.7\end{aligned}$ & $\begin{array}{r}\mathbf{7 . 3} \\
-1.2 \\
-6.2\end{array}$ & $\begin{array}{l}\text { nd } \\
\begin{array}{l}\mathbf{5 . 7} \\
-9\end{array}\end{array}$ & $\begin{array}{r}\mathbf{5 . 7} \\
1.9 \\
-2.2\end{array}$ & $\begin{aligned} & 2.6 \\
& 0 \\
- & 9.9\end{aligned}$ & $\begin{aligned} & 4.5 \\
& 0 \\
- & 7\end{aligned}$ & $\begin{array}{l}2.9 \\
0 \\
-0.2\end{array}$ & $\begin{aligned} & 3.6 \\
& 0 \\
- & 0.1\end{aligned}$ & $\begin{array}{c}0 \\
-0.2\end{array}$ \\
\hline 7 & $\mathrm{~F}$ & M & $\begin{array}{l}\text { IAA } \\
\text { GADAb } \\
\text { IA } 2 A b\end{array}$ & 1,13 & & & & & $\begin{array}{l}\text { nd } \\
2.6 \\
-6\end{array}$ & $\begin{array}{r}7.7 \\
9.2 \\
-4.9\end{array}$ & $\begin{array}{r}5.3 \\
3.6 \\
-3.9\end{array}$ & & & & \\
\hline 8 & M & $\mathrm{F}$ & $\begin{array}{l}\text { IAA } \\
\text { GADAb } \\
\text { IA } 2 \mathrm{Ab}\end{array}$ & 3,12 & & $\begin{array}{r}\mathbf{6 . 1} \\
\mathbf{5 . 1} \\
-4.7\end{array}$ & $\begin{array}{l}5.4 \\
2.4 \\
1.4\end{array}$ & $\begin{array}{c}\mathbf{8} \\
2.4 \\
-5.7\end{array}$ & $\begin{aligned} & 3.7 \\
& 0.6 \\
- & 1\end{aligned}$ & $\begin{array}{l}3.1 \\
0 \\
-0.6\end{array}$ & $\begin{aligned} & 3.1 \\
& 0 \\
- & 0.9\end{aligned}$ & $\begin{array}{l}4.5 \\
0 \\
-0.3\end{array}$ & & $\begin{array}{l}3.5 \\
0 \\
0.1\end{array}$ & \\
\hline 9 & M & $\mathrm{S}$ & $\begin{array}{l}\text { IAA } \\
\text { GADAb } \\
\text { IA } 2 A b\end{array}$ & 3,12 & & & $\begin{array}{r}\text { nd } \\
4.7 \\
-9.4\end{array}$ & $\begin{array}{r}\mathbf{7 . 2} \\
\mathbf{5 . 9} \\
-8.3\end{array}$ & $\begin{array}{r}5.1 \\
4.7 \\
-8.1\end{array}$ & $\begin{array}{r}2.9 \\
1.1 \\
-9.1\end{array}$ & $\begin{array}{r}3.2 \\
0.6 \\
-9.6\end{array}$ & & $\begin{aligned} & 3.1 \\
& 0 \\
- & 0.1\end{aligned}$ & & 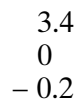 \\
\hline 10 & $\mathrm{M}$ & M & $\begin{array}{l}\text { IAA } \\
\text { GADAb } \\
\text { IA } 2 A b\end{array}$ & 3,7 & & $\begin{array}{r}\text { nd } \\
\mathbf{1 1 3} \\
0\end{array}$ & $\begin{array}{c}5.2 \\
43 \\
\mathbf{5 . 1}\end{array}$ & $\begin{array}{l}\text { nd } \\
4.7 \\
0\end{array}$ & $\begin{array}{r}6.3 \\
2.4 \\
-0.6\end{array}$ & $\begin{array}{l}3.5 \\
1.2 \\
0.2\end{array}$ & $\begin{array}{r}3.7 \\
0.7 \\
-0.4\end{array}$ & $\begin{array}{l}4.8 \\
4.7 \\
0.1\end{array}$ & $\begin{array}{r}3.2 \\
4.7 \\
-0.4\end{array}$ & & \\
\hline 13 & $\mathrm{~F}$ & $\mathrm{~F}$ & $\begin{array}{l}\text { IAA } \\
\text { GADAb } \\
\text { IA } 2 A b\end{array}$ & 3,3 & & $\begin{array}{l}4.8 \\
0 \\
1.5\end{array}$ & $\begin{array}{l}\text { nd } \\
8.5 \\
16\end{array}$ & $\begin{array}{l}2.6 \\
0 \\
8.2\end{array}$ & $\begin{array}{l}2.7 \\
0 \\
1.7\end{array}$ & $\begin{array}{l}2.2 \\
0 \\
-0.2\end{array}$ & $\begin{array}{l}1.5 \\
0 \\
-0.2\end{array}$ & $\begin{array}{l}3.4 \\
0 \\
-0.4\end{array}$ & $\begin{aligned} & 2.6 \\
& 0 \\
- & 0.7\end{aligned}$ & & \\
\hline 14 & $\mathrm{~F}$ & $\mathrm{~S}$ & $\begin{array}{l}\text { IAA } \\
\text { GADAb } \\
\text { IA } 2 \mathrm{Ab}\end{array}$ & 1,3 & & $\begin{array}{c}\text { nd } \\
0 \\
-1.1\end{array}$ & $\begin{aligned} & \mathbf{8 . 8} \\
& 0 \\
- & 5.8\end{aligned}$ & $\begin{array}{r}11 \\
1.8 \\
-3.5\end{array}$ & $\begin{array}{r}2.7 \\
\mathbf{5 . 3} \\
-8.8\end{array}$ & $\begin{array}{l}5.2 \\
1.6 \\
\mathbf{4 . 1}\end{array}$ & $\begin{array}{c}3 \\
0 \\
-1.7\end{array}$ & & & & \\
\hline 15 & M & $\mathrm{F}$ & $\begin{array}{l}\text { IAA } \\
\text { GADAb } \\
\text { IA } 2 \mathrm{Ab}\end{array}$ & 4,11 & & & & $\begin{aligned} & \mathbf{5 . 7} \\
& 2.9 \\
- & 9\end{aligned}$ & $\begin{array}{l}\text { nd } \\
2.7 \\
-8.3\end{array}$ & $\begin{aligned} & 4.8 \\
& 0 \\
- & 7.2\end{aligned}$ & $\begin{array}{c}\text { nd } \\
0 \\
-9.9\end{array}$ & $\begin{array}{r}5.4 \\
0.7 \\
-5.1\end{array}$ & $\begin{array}{r}5.4 \\
\mathbf{8 . 2} \\
-0.4\end{array}$ & $\begin{array}{c}4.7 \\
\mathbf{1 4} \\
-0.1\end{array}$ & $\begin{array}{r}4.8 \\
9.5 \\
-0.3\end{array}$ \\
\hline 16 & M & M & $\begin{array}{l}\text { IAA } \\
\text { GADAb } \\
\text { IA2Ab }\end{array}$ & nd & & & $\begin{array}{l}1.6 \\
3.4 \\
0\end{array}$ & $\begin{array}{l}2.6 \\
3.2 \\
0\end{array}$ & $\begin{array}{l}\quad 6.2 \\
0 \\
-3.2\end{array}$ & & $\begin{array}{l}2.5 \\
9 \\
0.4\end{array}$ & $\begin{array}{l}2 \\
0.1 \\
0.5\end{array}$ & $\begin{array}{l}3.6 \\
0\end{array}$ & $\begin{array}{l}3.4 \\
0 \\
0\end{array}$ & \\
\hline 17 & M & $\mathrm{M}$ & $\begin{array}{l}\text { IAA } \\
\text { GADAb } \\
\text { IA } 2 A b\end{array}$ & 3,4 & & & $\begin{array}{r}\text { nd } \\
0.9 \\
-6.7\end{array}$ & $\begin{array}{c}\mathbf{6} \\
\mathbf{6 1} \\
-5.8\end{array}$ & $\begin{array}{l}9.4 \\
52 \\
67\end{array}$ & $\begin{array}{l}10 \\
24 \\
95\end{array}$ & $\begin{array}{l}9.3 \\
3.4 \\
99\end{array}$ & $\begin{array}{l}10.4^{*} \\
11 \\
83\end{array}$ & & & \\
\hline 18 & $\mathrm{~F}$ & $\mathrm{M}$ & $\begin{array}{l}\text { IAA } \\
\text { GADAb } \\
\text { IA } 2 A b\end{array}$ & 3,4 & & $\begin{array}{r}\text { nd } \\
\text { nd } \\
0\end{array}$ & $\begin{array}{l}\text { nd } \\
0 \\
6.9\end{array}$ & $\begin{array}{c}2.8 \\
49 \\
\mathbf{7 . 7}\end{array}$ & $\begin{array}{l}3.5 \\
\mathbf{5 5} \\
\mathbf{3 6}\end{array}$ & & & & & $\begin{array}{l}5.8 \\
51 \\
81\end{array}$ & \\
\hline 19 & M & $\mathrm{F}$ & $\begin{array}{l}\text { IAA } \\
\text { GADAb } \\
\text { IA } 2 A b\end{array}$ & 1,4 & & $\begin{array}{c}\text { nd } \\
0 \\
-4.4\end{array}$ & $\begin{array}{l}2.4 \\
0 \\
-6.6\end{array}$ & $\begin{array}{l}\quad 4 \\
0 \\
-1.2\end{array}$ & $\begin{aligned} & 3.3 \\
& 0 \\
- & 7.2\end{aligned}$ & $\begin{array}{l}2 \\
0.5 \\
-0.2\end{array}$ & $\begin{array}{c}4.8 \\
\mathbf{1 5} \\
-0.1\end{array}$ & $\begin{array}{c}4.7 \\
\mathbf{5 8} \\
-0.2\end{array}$ & $\begin{array}{c}\mathbf{6 . 7} \\
\mathbf{6 6} \\
-0.1\end{array}$ & 83 & \\
\hline
\end{tabular}


Table 2. (Continued)

\begin{tabular}{|c|c|c|c|c|c|c|c|c|c|c|c|c|c|c|c|}
\hline \multirow[t]{2}{*}{ Infant } & \multirow[t]{2}{*}{ Sex } & \multirow[t]{2}{*}{ Proband } & \multirow[t]{2}{*}{ Antibody } & \multirow{2}{*}{$\begin{array}{l}\text { HLA } \\
\text { DR }\end{array}$} & \multicolumn{11}{|c|}{ Age (Months) } \\
\hline & & & & & $\overline{0}$ & 6 & 12 & 18 & 24 & 30 & 36 & 42 & 48 & 54 & 60 \\
\hline 20 & $\mathrm{M}$ & $\mathrm{M}$ & $\begin{array}{l}\text { IAA } \\
\text { GADAb } \\
\text { IA } 2 \mathrm{Ab}\end{array}$ & 3,4 & & & & & & & & $\begin{array}{l}5.2 \\
\mathbf{1 1} \\
\mathbf{9 9}\end{array}$ & $\begin{array}{r}8.7 \\
3.7 \\
99\end{array}$ & $\begin{array}{c}20 \\
6.5 \\
88\end{array}$ & $\begin{array}{r}12.9 \\
2.4 \\
91\end{array}$ \\
\hline 21 & M & $\mathrm{M}$ & $\begin{array}{l}\text { IAA } \\
\text { GADAb } \\
\text { IA } 2 A b\end{array}$ & 3,4 & & $\begin{array}{r}2 \\
\mathbf{5 . 2} \\
-0.3\end{array}$ & $\begin{array}{c}5 \\
\mathbf{1 4} \\
-0.4\end{array}$ & $\begin{array}{l}6.8 * \\
36 \\
77\end{array}$ & & & & & & & \\
\hline 23 & $\mathrm{~F}$ & $\mathrm{~F}$ & $\begin{array}{l}\text { IAA } \\
\text { GADAb } \\
\text { IA } 2 A b\end{array}$ & 4,7 & & $\begin{array}{l}3.7 \\
0 \\
1.5\end{array}$ & & $\begin{array}{c}3.2 \\
\mathbf{1 3} \\
-1.4\end{array}$ & $\begin{array}{l}5.8 \\
45 \\
63\end{array}$ & $\begin{array}{l}3.9 \\
\mathbf{6 3} \\
\mathbf{8 1}\end{array}$ & $\begin{array}{l}4.2 \\
\mathbf{4 3} \\
\mathbf{9 8}\end{array}$ & $\begin{array}{l}4.3 \\
\mathbf{2 6} \\
\mathbf{9 8}\end{array}$ & $\begin{array}{l}2.3 \\
\mathbf{3 5} \\
\mathbf{9 6}\end{array}$ & & \\
\hline 24 & $\mathrm{~F}$ & $\mathrm{M}$ & $\begin{array}{l}\text { IAA } \\
\text { GADAb } \\
\text { IA } 2 A b\end{array}$ & 4,4 & & & $\begin{aligned} & 5 \\
& 0 \\
- & 7.1\end{aligned}$ & & $\begin{array}{c}5.7 \\
12 \\
-8\end{array}$ & $\begin{array}{l}51^{*} \\
49 \\
32\end{array}$ & & & & & \\
\hline
\end{tabular}

Table 3. First antibody detected in infants with two or more antibodies

\begin{tabular}{lll}
\hline $\begin{array}{l}\text { First antibody } \\
\text { detected }\end{array}$ & $\begin{array}{l}\text { Number } \\
\text { of infants }\end{array}$ & $\begin{array}{l}\text { Age at detection } \\
\text { (months) }\end{array}$ \\
\hline IAA & 8 & $12(\times 3), 18,24(\times 3), 30$ \\
GADAb & 5 & $6,18,36(\times 2), 54$ \\
IA2Ab & 2 & $18(\times 2)$ \\
IAA and GADAb & 5 & $6,18(\times 2), 24,30$ \\
IAA and IA2Ab & 2 & 6,18 \\
GADAb and IA2Ab & 2 & 12,24 \\
All three antibodies & 1 & 18 \\
\hline
\end{tabular}

body detected on more than one occasion and $7 \%$ had two or more antibodies.

In infants who developed a single antibody transiently, IAA and IA2Ab were detected more frequently than GADAb but there was no difference in the age at which individual antibodies were detected. These antibodies were generally at a low level and their significance remains uncertain. Their transient nature presumably means that the antigenic stimulus to their synthesis is non-sustained and their low levels then disappear rapidly due to tissue fixation. In these infants HLA DR alleles were not different from the group as a whole. In infants with a single antibody detected on more than one occasion, IAA were twice as frequent as either GADAb or IA $2 \mathrm{Ab}$, but in contrast to GADAb, IAA and IA $2 \mathrm{Ab}$ positivity was not sustained. The HLA DR alleles of infants with persistent GADAb are 7,8; 3,$4 ; 11,6 ; 11,14$ and these infants are being followed closely for the development of other antibodies. Their risk for diabetes, however, is probably low as ICA were negative in all four.
Multiple antibodies are much more commonly associated with progression to Type I diabetes [5-7] and therefore it is likely that the infants with a single antibody are not at an increased risk. It is not known, however, whether transient islet autoimmunity in these children is really self-limited or could recur. Longer follow-up will be required to determine whether other antibodies develop and whether this group is at an increased risk for diabetes. It must be conceded, however, that the relatively high frequency of IAA could be at least partly explained by the assay method. To conserve serum we measured only total insulin binding and could have included some false positives. A recently-described microassay [20] appears to provide similar results as the conventional IAA assay [21] and should be especially useful in further studies of infants.

Infants who developed two or more antibodies are potentially at an increased risk. This group, however, is heterogeneous and includes 15 subjects $(1-14,16)$ with two or more antibodies on one or more occasions but subsequently antibody negative on one or more occasions. The remaining 10 subjects (15, $17-25), 2.8 \%$ of the total study group, were repeatedly antibody positive and included the four who developed diabetes. All of the infants who developed diabetes had two or more antibodies detected prior to diagnosis. Compared with the total group, there was a significant increase in HLA DR4 $(p<0.01)$ and HLA DR3,4 $(p<0.05)$ in these. This is in accord with the German BABYDIAB study [12] in which HLA DR3,4 and HLA DR4,4 were seen in half the offspring who developed antibodies.

Thus, although a large proportion $(27 \%)$ of the infants studied had antibodies, a much smaller propor- 
tion $(7 \%)$ had two or more antibodies. A smaller proportion $(2.8 \%)$ had two or more antibodies repeatedly and four $(1 \%)$ developed diabetes. In the infants who developed multiple antibodies, there had been no typical sequence of development of autoantibodies. A predominant marker was IAA, being the first antibody detected in $64 \%$ of infants who developed two or more antibodies. This frequency is less than recently reported for the German BABYDIAB study in which IAA was detected first in 22 of 23 offspring with multiple antibodies [11]. On the basis of our study, however, we are unable to confirm that IAA are always the first autoantibodies to be detected.

We conclude that serial screening for islet antibodies from birth can identify infants at risk for diabetes. Many more children, however, have detectable antibodies than would be expected to develop diabetes. A proportion of this positivity is possibly due to assay imperfections or difficulties in defining cut-off limits. Nevertheless, these findings indicate that transient islet autoimmunity is relatively common and does not presage diabetes in infants who have a first-degree relative with Type I diabetes.

Acknowledgements. We thank C. Jankulovski and E. Fleming for laboratory assistance and M. Falanga for expert secretarial assistance. The study was supported by funding from the $\mathrm{Na}$ tional Health and Medical Research Council of Australia, the Victorian Health Promotion Foundation, Channel 7 Research Foundation of South Australia, Women's and Children's Hospital Research Foundation, Diabetes Australia Research Trust and Variety Club of South Australia. We especially thank all the families in the study.

\section{References}

1. Harrison LC, Campbell IL, Colman PG et al. (1990) Type I diabetes: immunopathology and immunotherapy. Adv Endocrinol Metab 1: 36-94

2. Srikanta S, Ganda OP, Rabizadeh A, Soeldner JS, Eisenbarth GS (1985) First-degree relatives of patients with type I diabetes mellitus. Islet cell antibodies and abnormal insulin secretion. N Engl J Med 313: 461-464

3. Bonifacio E, Bingley PJ, Shattock M et al. (1990) Quantification of islet-cell antibodies and prediction of insulin-dependent diabetes. Lancet 335: 147-149

4. Riley WJ, Maclaren NK, Krischer J et al. (1990) A prospective study of the development of diabetes in relatives of patients with insulin-dependent diabetes. N Engl J Med 323: 1167-1172

5. Bingley PJ, Christie MR, Bonifacio E et al. (1994) Combined analysis of autoantibodies improves prediction of IDDM in islet cell antibody-positive relatives. Diabetes 43: $1304-1310$

6. Bonifacio E, Genovese S, Braghi S et al. (1995) Islet autoantibody markers in IDDM: risk assessment strategies yielding high sensitivity. Diabetologia 38: 816-822
7. Verge CF, Gianani R, Kawasaki E et al. (1996) Prediction of type I diabetes in first-degree relatives using a combination of insulin, GAD, and ICA512bdc/IA-2 autoantibodies. Diabetes 45: 926-933

8. Colman PG, McNair P, Margetts H et al. (1998) The Melbourne Pre-Diabetes Study: prediction of Type I diabetes mellitus using antibody and metabolic testing. Med J Aust 169: 81-84

9. Ziegler AG, Hillebrand B, Rabl W et al. (1993) On the appearance of islet associated autoimmunity in offspring of diabetic mothers: a prospective study from birth. Diabetologia 36: 402-408

10. Roll U, Christie MR, Füchtenbusch M, Payton MA, Hawkes CJ, Ziegler AG (1996) Perinatal autoimmunity in offspring of diabetic parents. The German Multi-Center BABY-DIAB study: detection of humoral immune responses to islet antigens in early childhood. Diabetes 45 : 967-973

11. Ziegler A-G, Hummel M, Schenker M, Bonifacio E (1999) Autoantibody appearance and risk for development of childhood diabetes in offspring of parents with Type I diabetes. The 2-year analysis of the German BABYDIAB study. Diabetes 48: 460-468

12. Schenker M, Hummel M, Ferber K et al. (1999) Early expression and high prevalence of islet autoantibodies for DR3/4 heterozygous and DR4/4 homozygous offspring of parents with Type I diabetes: The German BABYDIAB study. Diabetologia 42: 671-677

13. Rewers M, Bugawan TL, Norris JM et al. (1996) Newborn screening for HLA markers associated with IDDM: diabetes autoimmunity study in the young (DAISY). Diabetologia 39: 807-812

14. Hahl J, Simell T, Ilonen J, Knip M, Simell O (1998) Costs of predicting IDDM. Diabetologia 41: 79-85

15. Norris JM, Beaty B, Klingensmith G et al. (1996) Lack of association between early exposure to cow's milk protein and $\beta$-cell autoimmunity: Diabetes Autoimmunity Study in the Young (DAISY). JAMA 276: 609-614

16. Couper JJ, Steele C, Beresford S et al. (1999) Lack of association between duration of breast feeding or introduction of cow's milk and development of islet autoimmunity. Diabetes 48: 2145-2149

17. Vardi P, Dib SA, Tuttleman M et al. (1987) Competitive insulin autoantibody assay. Prospective evaluation of subjects at high risk for development of type I diabetes mellitus. Diabetes 36: 1286-1291

18. Terasaki PI, McClelland JD (1964) Microdroplet assay of human serum cytokines. Nature 204: 998-1000

19. Kimura A, Sasazuki T (1991) Eleventh International Histocompatibility Workshop reference protocol for the HLA-DNA typing technique. In: Tsuji K, Aizawa M, Sasazuki T (eds) HLA 1991. Proceedings of the 11th International Histocompatibility Workshop and Conference. Oxford University Press, Oxford, p 419

20. Williams AJK, Bingley PJ, Bonifacio E, Palmer JP, Gale EAM (1997) A novel micro- assay for insulin autoantibodies. J Autoimmun 10: 473-478

21. Naserke HE, Dozio N, Ziegler A-G, Bonifacio E (1998) Comparison of a novel micro-assay for insulin autoantibodies with the conventional radiobinding assay. Diabetologia 41: 681-683 